\title{
Wealth Effect and Macroeconomics Factors of a Firm's International Merger and Acquisition Exercise: Empirical Evidence from Multinational Firms
}

\author{
Bany Ariffin Amin Noordin, Fakarudin Kamarudin, Nazratul Aina Mohamad Anwar
}

\author{
Universiti Putra Malaysia \\ 43400 Serdang, Selangor Darul Ehsan, Malaysia \\ E-mail.bany@upm.edu.my,fakarudin@upm.edu.my,nazratulaina84@gmail.com
}

cross $^{\text {ref }}$ http://dx.doi.org/10.5755/j01.ee.26.5.11418

\begin{abstract}
The aim of this study is to examine the influence of macroeconomic factors on the wealth effects of international merger and acquisitions by Malaysian multinational companies (MNCs). There are three macroeconomics factors: foreign economic condition, gross national product (GNP) correlation between countries and the level of the economic development of a target country. A random sample of 165 international mergers and acquisitions by Malaysian bidding MNCs in 22 countries around the world in the period of 2000-2010 was recruited for this study. A negative relationship between the foreign economic condition and the wealth effect and a positive relationship between the level of economic development of target country and the wealth effect has been found through this study. This implies that the foreign economic condition and level of economic development of the target country significantly determine the value creation of the Malaysian cross-border acquisitions. Therefore, Malaysian MNCs, which intend to use the acquisition mode of entry as the way to venture abroad, should take into consideration these macroeconomic factors in order to increase their foreign investment value.
\end{abstract}

Keywords: Macroeconomic Factors, Firm's Wealth, International Merger and Acquisitions, Malaysian Multinational Companies.

\section{Introduction}

To date, studies on the impact of local mergers and acquisitions (M\&A) on the wealth of firms' shareholders have been carried out in significant numbers. Yet, the results are still inconclusive. (Cartwright \& Schoenberg, 2006; Homberg et al., 2009; Sufian et al., 2013b) indicate that within-border M\&As lead to the wealth effect range from value-addictive to value-neutral based on the meta analysis. In addition, compared to diversification in a cross-corporate portfolio, there are also advantages that could lead to cross-border diversification via M\&As on firms that are not fully realized by investors. Hence, crossborder diversification is expected to create a greater wealth effect due to a firm's greater ability to exploit its strategic advantage regarding countries' differences in macroeconomics factors.

Manzon et al., (1994) suggest that, US multinationals obtained incremental benefits from their foreign acquisitions. (Evenett, 2003) shows that a group of characteristics of the target country are important determinants for profitable acquisitions. In addition, (Rossi \& Volpin, 2004) discover that there is a negative association between the level of investor protection and the volume of M\&A activities and that targets are more likely to be from countries with poorer investor protection, while buyers are more likely to be from countries with stronger investor protection.

In accordance with the expectations listed above, the advantages of country diversification are argued to have a significant relationship with the level of difference in the macroeconomics factors of the countries. This can be further explained by the fact that greater difference in macroeconomic factors of countries potentially leads to higher chances for firms to realize the advantages brought by country diversification. Thus, in this study, abnormal returns are hypothesized to be significantly associated with the macroeconomic factors of the host countries.

The main purpose of this study is to examine the influence of macroeconomic factors on the wealth effects of international M\&As by Malaysian multinational companies (MNCs). Furthermore, this study also takes into consideration the effect of macroeconomic factors of the host countries on the wealth effect of the firms. Throughout the years, among the Asian developing countries, Malaysia has been established as the target of foreign direct investment (FDI) flows from developed nations. Figure 1 shows that Malaysia becomes one of the top 10 FDI from South, East, and South-East Asia for 2008-2009, or the leader of other ASEAN neighboring countries.

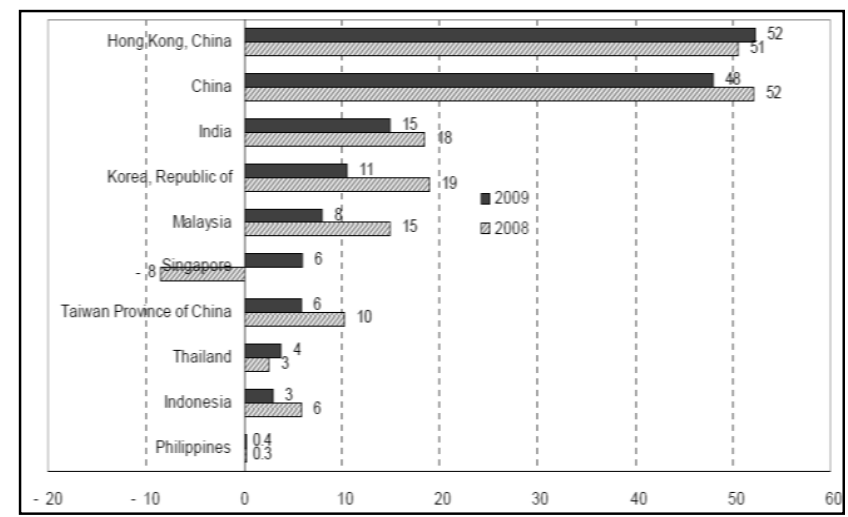

Figure 1. Top 10 FDI sources in South, East and South-East Asia 2008-2009 (Billion of Dollars) Source: UNCTAD (2010) 
Outward foreign direct investment (OFDI) has been initiated by Malaysian companies since the mid-1970s. Malaysia then has become aggressively involved in abroad investment activities starting from year 1993. The OFDI of Malaysia has increased tremendously from USD 129 million to USD 2,971 million of the FDI outflows for the duration of 1990-2005 (UNSTAD, 2006). Therefore, Malaysia today is being identified as an essential contributor to OFDI from the Asian developing economies.

In addition to the OFCI from Malaysia, there is also trend regarding the issue of international M\&As. In order to expand, diversify, or develop MNCs' business in the international markets, M\&As are being identified as the key corporate strategies. However, little attention has been devoted to studies on M\&A. (Lee \& Mansor, 2008) investigate the performance of long-term shares by using a sample of acquiring firms listed on the Malaysian stock exchange from 2000 to 2004. In addition, an earlier study by Fauzias $(1992,1993)$ examines the efficiency of the Malaysian stock market's reaction to acquisition announcements and the influences of acquisition announcement on the price behavior of Malaysian bidders and target firms by utilizing two factor market models: the Capital Asset Pricing Model and regression estimation model. Furthermore, prior works, such as (Kueh et al., 2009) discuss the effect of macroeconomic variables on the overall outward FDI from Malaysia, yet this study does not emphasize cross-border acquisitions.

Therefore, this study aims to contribute to the scarce existing literature regarding Malaysian OFDI, particularly on cross-border acquisition issues from the view of macroeconomics. This study is also bringing further understanding and suggestions on the influence of macroeconomics factors on cross-border M\&A by MNCs in developing nations.

The organization of this study is as follows. The next section provides the literature regarding the evolution of Malaysian MNCs. The sample selection and methodology will then be described in Section 3. Section 4 demonstrates the results and findings on the wealth effect of the foreign M\&A exercise and the factors that affect wealth effects. The final section includes the conclusion.

\section{Literature Review}

(Billington, 1999; Schneider \& Frey, 1985; Trevino et al., 2002) believed that the foreign investment activities, particularly the cross-border acquisitions, are determined by the favorable foreign economy, which is reflected by the size of the potential market, economic growth, and the macroeconomic environment stability.

However, there are also different perspectives regarding the favorable foreign economic condition. (Kiymaz, 2004) argues that the more favorable the foreign economic conditions, the more negotiation power a target would gain, and hence, the premium to obtain the foreign target would be higher. The overpaying premium will then turn into negative wealth gains to the bidders.

Sufian \& Kamarudin, (2014) suggest, decision-makers ought to be more cautious in promoting M\&As among the large banks as a means to enjoying efficiency gains. The results seem to suggest that further increase in size would only result in a smaller increase of outputs for every proportionate increase in inputs for the large banks. It would be interesting to investigate the MNCs' response on the effects of a foreign economic condition for their crossborder acquisitions in the Malaysian context due to the mixed findings and discussions.

Heston \& Rouwenhorst (1994) find that the diversification across countries within the same industry is more effective in reducing risk and, therefore, this crossborder diversification increases the firm value. This is also supported by (Kiymaz \& Muhkerjee, 2000), where the differences among countries in financial or products markets influence the degree of the co-movement of the economies between any two countries. Here, the divergence is negatively associated with the co-movements and is also positively related to the firms' opportunities to realize the country's diversification benefits. Hence, the greater the product and financial market differences of the countries involved in the foreign investment activities, the greater the potential is from M\&A advantages and also the higher the positive abnormal returns are for the bidder.

The country diversification assists firms to gain benefits, for example, to increase cash flow or to reduce risk using cross-border acquisitions. This means that, by achieving cross-border acquisition, the divergence in international capital and product markets is accomplished by using the differences among countries. Therefore, the divergence in international capital and product market creates value for the bidders and increases the wealth effects of the cross-border acquisitions. Hence, the diversification effect on the wealth gains of bidders, which is indicated by the GNP correlation between countries, is expected to relate to the cross-border acquisitions by Malaysian MNCs.

Frenkel et al., (2004) make the argument that, by having both the source and host country of international capital flows in developed countries, developed countries are the main destination of foreign direct investment. Similarly, (Markusen, 1998) also find that, due to the firms' intention to seek the market in order to either expand into similar markets or protect their home market from foreign competition, most FDIs target high-income developed countries.

Bany-Ariffin \& Fauzias (2006) identify that, from the view of wealth effect, developed countries are favorable by Malaysian MNCs in doing foreign investments, as compared to developing countries. This is because there is greater political risk, which potentially deteriorates the long-term plans and profitability of the MNCs in developing countries. From the view of the valuation effect, foreign investment is less favorable in developing countries due to the greater uncertainty in the operating environment in which there are incomplete and improper infrastructures and development, as compared to developed countries. This might destroy the Malaysian MNCs' foreign operations and markets. It can be concluded that there are benefits to engaging in foreign direct investment to attract capital inflows in both developed and developing countries. In this analysis, Malaysian bidding MNCs are more strongly emphasized regarding the economic development level that leads to wealth gains to the bidders. 
In short, all the macroeconomics factors namely, foreign economic condition, GNP correlation between countries and the level of the economic development of a target country may influence the wealth effects of international M\&As by Malaysian MNCs.

\section{Methodology \& Sample}

\section{Model Employed}

In this study, in order to measure the impact of crossborder acquisition activities on the wealth effects of Malaysian bidding MNCs, standard event-study methodology is utilized as according to (Brown \& Warner, 1985). As suggested by (Fama, 1976), this event-study methodology is based on a market model to compute the expected return of the firms given the market return and the historical association of the firms and market.

The assumption under this method is that the efficiency of capital markets is in a semi-strong form. In a capital market with semi-strong efficiency, the security's price incorporates all currently available public information and also adjusts to the public announcement of new and prompt information.

Therefore, the market model used to estimate the expected return for each MNC's M\&A announcement is as follows,

$$
\begin{aligned}
& E R_{i t}=a_{i}+b_{i} R_{m t}+e_{i t} \\
& \text { Where: } \\
& E R_{i t}=\text { expected return on the security of firm } \\
& \mathrm{i} \text { at time } \mathrm{t} \\
& R_{m t}=\text { return on the market portfolio at time } \mathrm{t} \text {, } \\
& b_{i} \quad \text { and that of the market } \\
& e_{i t}=\text { residual of the relationship at time } \mathrm{t}
\end{aligned}
$$

The estimated parameters for each security i over the period of 3 years prior to the announcement of the foreign acquisitions here are represented by the alpha (ai) and beta (bi). The expected returns over the test period are computed by utilizing these parameters.

The abnormal returns $\left(A R_{i t}\right)$ are defined as the difference between the actual returns $\left(R_{i t}\right)$ and the expected returns $\left(E R_{i t}\right)$ for each day and for each firm. Hence, abnormal returns are calculated as follows:

$$
A R_{i t}=R_{i t}-E R_{i t}
$$

Where:

$$
E R_{i t}=a_{i}+b_{i} R_{m t}
$$

$$
\begin{aligned}
& \text { or } \\
& A R_{i t}=R_{i t}-\left(a_{i}+b_{i} R_{m t}\right)
\end{aligned}
$$

Where $a$ and $b$ are the estimated parameters $a$ and $b$ of firm i. In order to estimate the abnormal returns (AR) of each company stock, the event period of 20 days $(t=-10$ to $\mathrm{t}=+10)$ is used. If there is no effect of foreign acquisition announcement on stock price, the abnormal returns should be zero (0). Furthermore, in order to drive the overall conclusion for the event of interest, all of the firm's abnormal return observations are accumulated. The study used the average effects of the announcement as an alternative of each firms separately, due to the effect of other events' potential to be minimized among existing and averaging all firms. Thus, a daily average AR for each day $\mathrm{t}$, for a sample of $\mathrm{N}$ firms, is as follows:

$$
A R_{t}=\quad 1 / N\left(\sum_{j=1}^{n} A R \mathrm{jt}\right)
$$

The t-test statistic on any day $t$ in the event window for all $\mathrm{n}$ stocks is created to investigate the influence of crossborder acquisition announcement on stock returns, which is hypothesized to provide a significant average daily abnormal return. The t-statistic is as follows:

$$
t_{-} \quad=A R_{i t} / \sigma A R_{t}
$$

statistic

Where:

$\sigma A R_{t} \quad$ standard deviation of average AR over the event period of $(\mathrm{t}=-10$ to $\mathrm{t}=+10)$

If the foreign acquisitions do not influence the respective common stock return, the daily average AR for all sample stocks within the event period therefore should not be statistically significantly different from zero.

\section{Cross-sectional Regression Model}

The influence of macroeconomic factors on the wealth effects of international merger and acquisitions by Malaysian multinational companies (MNCs) over the years are examined through the cross-sectional regression analysis model

By using the cumulative abnormal returns scores as dependent variable, we developed the following regression model:

$$
\begin{aligned}
& C A R=\beta_{0}+\beta_{1 F O R E C O}+\beta_{2 G N P C O R}+\beta_{3 L D E V E L O P}+ \\
& \beta_{4 L A N G U A G E}+\beta_{\text {SLAWRULE }}+\beta_{\text {6INFRATEL }}+\varepsilon
\end{aligned}
$$

Where:

$\begin{array}{lll}\text { CAR } & = & \text { cumulative abnormal returns } \\ \text { FORECO } & = & \text { foreign economic conditions } \\ \text { GNPCOR } & = & \text { gross national product } \\ \text { DEVELOP } & = & \text { level of economic development } \\ \text { LANGUANGE } & = & \text { language } \\ \text { LAWRULE } & = & \text { rule of law } \\ \text { INFRATEL } & = & \text { telecommunication } \\ \beta & & \text { infrastructure } \\ \beta & = & \text { vector of coefficients } \\ \varepsilon & = & \text { normally distributed } \\ & & \text { disturbance term }\end{array}$

Furthermore, to avoid severe multicollinearity problems, we adopt a step-wise regression models suggested by (Sufian et al., 2014; Kamarudin et al., 2014a\&b; Kamarudin et al., 2013; Sufian et al., 2012; Sufian et al. 2013a). Accordingly, 3 regression models are estimated to examine the relationship between macroeconomic factors on the wealth effects of international merger and acquisitions by Malaysian MNCs. 
Bany Ariffin Amin Noordin, Fakarudin Kamarudin, Nazratul Aina Mohamad Anwar. Wealth Effect and Macroeconomics...

\section{Sample Selection}

The population for this study includes 165 announcements of foreign acquisition by Malaysian companies, which are dispersed among 22 countries around the world from 2000 to 2010 , according to the geographical spread of the foreign investment activities by Malaysian MNCs, which are published by Bursa Malaysia. Table 1 shows the statistic of FDI announcements of foreign acquisition and the regional spread of these foreign investment activities, which consists of 5 continents of the world in 22 countries.

Table 1

Number of cross-border M\&A by Malaysian MNCs

\begin{tabular}{|c|c|c|}
\hline Region & Number of M\&A & Total \\
\hline \multicolumn{3}{|c|}{ Asia } \\
\hline Cambodia & 6 & \multirow{9}{*}{104} \\
\hline China & 28 & \\
\hline India & 9 & \\
\hline Indonesia & 13 & \\
\hline Japan & 6 & \\
\hline Philippines & 10 & \\
\hline Singapore & 17 & \\
\hline Thailand & 8 & \\
\hline Vietnam & 7 & \\
\hline \multicolumn{3}{|c|}{ Africa } \\
\hline Egypt & 10 & \multirow{5}{*}{44} \\
\hline Ghana & 10 & \\
\hline Nigeria & 6 & \\
\hline South Africa & 14 & \\
\hline Sudan & 4 & \\
\hline \multicolumn{3}{|c|}{ North America } \\
\hline Canada & 2 & \multirow{2}{*}{7} \\
\hline USA & 5 & \\
\hline \multicolumn{3}{|c|}{ South America } \\
\hline Brazil & 2 & \multirow{2}{*}{3} \\
\hline Chile & 1 & \\
\hline \multicolumn{3}{|c|}{ Europe } \\
\hline Italy & 2 & \multirow{4}{*}{7} \\
\hline Netherland & 1 & \\
\hline Sweden & 1 & \\
\hline United Kingdom & 3 & \\
\hline Total & & 165 \\
\hline
\end{tabular}

The sample for this study consists of the 165 foreign M\&A announcements. In order to investigate the impact of cross-border activities on the Malaysian stock market to the extent of whether wealth gains to the shareholders exist for the firms involved, these cross-border activities conducted by Malaysian MNCs for the period for 2000-2010 are considered in this study.

\section{Data Collection}

The data for this study is primarily obtained from secondary data sources, including companies' annual reports, UNSTAD (United Nations Conference on Trade and Development) reports, World Bank Investment reports, data stream for daily share prices of each firm and the share prices of Malaysia Stock Exchange composite.

The Malaysia Stock Exchange Announcements Board is used to obtain the announcements of foreign acquisition by Malaysian MNCs. The reports issued by UNCTAD and World Bank have published all of the information and indexes relevant to trade and development issues and are used to obtain the data for the macroeconomic variables.

\section{Overall Sample}

Table 2 summarized, on average, the daily abnormal returns (AARs) are 4,012 \% and 3,185\% on day -1 and 0 , respectively. These results are statistically significant at the 0,01 level. Information leakage prior to the announcement occurs, indicated by the positive and statistically significant AARs on day -4 and -2 . The AARs on day +1 and +2 are found to be negative and significant at the 0,05 level, which is consistent with a market adjustment after the announcement. These findings imply that foreign acquisition announcements do produce new relevant information which creates movement in the market and also that investors generally favorably respond to the foreign international acquisition efforts of Malaysian-listed MNCs.

The findings indicate that the foreign investment activities by the MNCs of Malaysia in the form of M\&As are adding value to Malaysian firms for shareholders, which is consistent with the findings of (Biswas et al., 1997; Kiymaz, 2004). The study reports that international expansion via M\&A is beneficial to shareholders of firms that engage in such activities.

Table 2

Average daily abnormal returns (AARs)

\begin{tabular}{ccc}
\hline Days & AARs (\%) & t-statistic \\
\hline-10 & $-0,175$ & $-1,357$ \\
-9 & 0,115 & $-0,124$ \\
-8 & 0,457 & 1,611 \\
-7 & 0,325 & 1,511 \\
-6 & 0,565 & $1,753^{*}$ \\
-5 & 0,335 & 1,459 \\
-4 & 0,515 & $3,655^{* * *}$ \\
-3 & 0,115 & 0,871 \\
-2 & 0,551 & $2,459^{* *}$ \\
-1 & 4,012 & $18,157^{* * *}$ \\
0 & 3,185 & $10,251^{* * *}$ \\
1 & $-0,855$ & $-2,154^{* *}$ \\
2 & $-0,165$ & $-2,332^{* *}$ \\
3 & 0,185 & 0,456 \\
4 & 0,112 & 0,657 \\
5 & $-0,316$ & $-0,869$ \\
6 & 0,322 & 0,757 \\
7 & $-0,195$ & $-0,543$ \\
8 & $-0,185$ & $-0,343$ \\
9 & $-0,153$ & 1,553 \\
10 & 0,157 & 1,672 \\
\hline
\end{tabular}

Table 3 reveals the six different cumulative abnormal returns (CARs) for the firms. The CARs for the entire sample are $8,907 \%(5,78)$ and statistically significant.

Table 3

Cumulative abnormal returns (CARs) for selected windows

\begin{tabular}{lcc}
\hline \multicolumn{1}{c}{ Windows } & CARs (\%) & t-statistic \\
\hline CARs $(-1,0)$ & 7,202 & $19,20^{* * *}$ \\
CARs $(-1,1)$ & 6,341 & $13,25^{* * *}$ \\
CARs $(-5,5)$ & 7,674 & $6,16^{* * *}$ \\
CARs $(-10,10)$ & 8,907 & $5,78^{* * *}$ \\
CARs $(-10,2)$ & 8,982 & $3,25^{* * *}$ \\
CARs $(1,6)$ & $-0,717$ & $-2,65^{* * *}$ \\
\hline
\end{tabular}

Note: $* * *, * * *$ indicates significance at the $1 \%, 5 \%$ and $10 \%$ levels respectively

\section{Macroeconomic Variables}

The first indicator is the local economic condition of the target country (FORECO) variable, which is defined as the difference between the target country's GNP growth in 
the year prior to the announcement and the average GNP growth rate of the target country during the period of 2000-2007, divided by the average GNP growth rate of the target country during that period, based on (Kiymaz, 2004).

The second indicator is the GNP correlation between home and target countries (GNPCOR), which is defined as the correlation between the annual growth rates in GNPs of the two countries over a 10-year period ending the year before a merger. For instance, for an M\&A exercise in 2001, the correlation coefficient measures the relationship between the annual GNP growth rate of the previous 10year period (1991 to 2001). The same coefficient will be used with each M\&A activity if multiple M\&A activities involve the two-country exercise in 2001.

The third indicator is the level of economic development of target country (DEVELOP), which is divided into two categories using IMF's classification, developed and developing countries. A dummy variable is used, where one (1) represents the target country from the developed economy and zero (0) represents the target country from the developing economy.

\section{Control variables}

The control variables include language (LANGUAGE), the rule of law index (LAWRULE) and telecommunication infrastructure (INFRATEL). (Hisey \& Caves, 1985; Anderson \& Gatigon, 1986) point out that the cost for intercompany communication is lower when a country involved in the foreign investment activities uses common language. A dummy (LANGUAGE) is used for the language variable, where one (1) represents Englishspeaking foreign countries, and zero (0) represents nonEnglish speaking countries.
The government effectiveness of a foreign country is indicated by the rule of law index (LAWRULE). The effective government or policy do improve and assist in the operation of foreign investment activities. Hence, government effectiveness, which is represented by the rule of index, becomes one of the influencing factors on the wealth gains to the MNCs. For information, this variable is obtained from the World Bank Worldwide Governance Indicator.

(Bellak, 2009) reveals, the telecommunication infrastructure (INFRATEL) produces the demand for previous non-available goods and services at a reasonable price and hence, the trade in term of developing markets and wealth in previously untried fields could be improved. This variables measured by tele-density (number of telephones per 100 population) obtained from the World Development Indicator.

\section{Empirical results}

This study first investigate the degree of correlation between the independent variables that are used in the regression analysis. (Kennedy, 2008) assert that the multicollinearity problem in a regression model is considered as critical if the pair-wise or zero-order correlation coefficient between two regressions is excess of 0,8 . Table 4 shows that the absolute values of Spearman's correlation coefficients are relatively low and are less than 0,8 . This indicates that majority of the proposed determinants' variables do not possess multicollinearity problems for all the proposed models. Therefore, the analysis can be conducted on the selected variables.

Correlation Matrix for the Independent Variables

\begin{tabular}{|c|c|c|c|c|c|c|}
\hline & FORECO & GNPCOR & LDEVELOP & LANGUAGE & LAWRULE & INFRATEL \\
\hline FORECO & 1,000 & $-0,020$ & $-0,550 * * *$ & $0,362 * * *$ & $-0,289 * * *$ & $-0,538 * * *$ \\
\hline GNPCOR & & 1,000 & 0,016 & $-0,072 * *$ & $0,100 * * *$ & $-0,423 * * *$ \\
\hline LDEVELOP & & & 1,000 & $-0,224 * * *$ & $0,335^{* * *}$ & $0,445 * * *$ \\
\hline LANGUAGE & & & & 1,000 & $-0,087 * *$ & $-0,103 * * *$ \\
\hline LAWRULE & & & & & 1,000 & $0,151 * * *$ \\
\hline INFRATEL & & & & & & 1,000 \\
\hline
\end{tabular}

Note: The table presents the results from Spearman correlation coefficients.

***, **, * indicates significance at the $1 \%, 5 \%$ and $10 \%$ levels respectively.

Table 5 demonstrates the results of a cross-sectional regression analysis. There are three separate models for the regression results in Table 5. The first model utilizes macro variables to clarify the wealth effects. The second model exploits only the control variable, while the third model uses all of the variables. In general, the results report that the adjusted $\mathrm{R}^{2}$ falls between 0,050 and 0,159 and, besides, an F-value between 1,730 to 3,660 indicates that the regressions are statistically significant.

Table 5

\section{Cross-sectional regression analysis}

\begin{tabular}{lcccc}
\hline Variables & M1 & M2 & M3 \\
\cline { 5 - 5 } Constant & $\mathbf{- 0 , 3 4 8}$ & $\mathbf{0 , 0 2 9} *$ & $\mathbf{- 0 , 0 5 6}$ \\
\multirow{2}{*}{ FORECO } & $-0,669$ & $-0,017$ & $-0,622$ \\
& $\mathbf{- 0 , 0 3 3 * *}$ & - & $-\mathbf{0 , 0 3 9 * *}$ \\
& $-0,015$ & & $-0,018$ \\
\hline
\end{tabular}

\begin{tabular}{|c|c|c|c|}
\hline Variables & M1 & M2 & M3 \\
\hline \multirow[t]{2}{*}{ GNPCOR } & $-0,004$ & & $-0,041$ \\
\hline & $-0,003$ & & $-0,039$ \\
\hline \multirow[t]{2}{*}{ LDEVELOP } & $0,037 * * *$ & - & $0,285 * *$ \\
\hline & $-0,014$ & & $-0,124$ \\
\hline \multirow[t]{2}{*}{ LANGUAGE } & - & $-0,003$ & $-0,223^{*}$ \\
\hline & & $-0,01$ & $-0,125$ \\
\hline \multirow[t]{2}{*}{ LAWRULE } & - & $-0,028 * *$ & $-0,045 * *$ \\
\hline & & $-0,012$ & $-0,022$ \\
\hline \multirow[t]{2}{*}{ INFRATEL } & - & $\mathbf{0 , 0 1 7} * *$ & $0,024 *$ \\
\hline & & $-0,009$ & $-0,013$ \\
\hline $\mathbf{R}^{2}$ & 0,075 & 0,094 & 0,172 \\
\hline Adj. $R^{2}$ & 0,050 & 0,060 & 0,159 \\
\hline F-Value & $1,730 * *$ & $2,340 * *$ & $3,660 * * *$ \\
\hline \multicolumn{4}{|c|}{$\begin{array}{l}\text { Note: } * * *, * *, * \text { indicates significance at the } 1 \%, 5 \% \text { and } 10 \% \\
\text { levels respectively. Figure in parentheses }() \text { are standard error }\end{array}$} \\
\hline
\end{tabular}


There is a negative relationship between the foreign economic conditions (FORECO) and wealth gains to the bidding firms in Malaysia. This can explain cases in which the better foreign economic conditions lead to lower wealth gains or wealth effects experienced by Malaysian MNCs, consistent with the previous findings by international acquisitions in which a higher premium needs to be paid by the bidders to the targets if the bidders acquire targets in more favorable economic conditions. This can be further explained when the higher price to acquire a target potentially leads to negative abnormal returns to a bidder, even though there is market potential to the bidder in favorable economic conditions (Madura \& Wiant, 1994). Hence, the more favorable foreign economic condition results in lower wealth effects to the bidders.

Globerman \& Shapiro (2005) also suggest that an expanding economy attracts both investors and also the investment by domestic companies. Here not only market potential has been indicated by growing economic conditions, but also the increasing market competition. Intense competition negatively effects the bidders; for example, the need for lowering price, enhancing quality and raising advertising. Hence, negative wealth effects might bring by the market with a favorable economy to bidding firms. This implies that the cross-border acquisition by Malaysian MNCs in the countries with expanding economic conditions might experience negative wealth gains.

Furthermore, the target country level of development (DEVELOP) is also statistically significant and positively associated with wealth effects. The positive coefficient result here shows that the wealth effects are positively associated with the cross-border acquisitions in the developed countries, as a dummy of one (1) represents the developed countries and zero (0) is the developing countries for this variable. These findings reveal that Malaysian MNCs prefer to conduct foreign investment activities in developed markets, which contradicts the previous findings by Waheed \& Mathur (1995), when the international acquisitions would obtain higher wealth gains to bidders in developing countries. However, the findings from this study are consistent with Bany-Ariffin \& Fauzias (2006). They discover that the foreign investments by Malaysian MNCs yield higher positive returns for their shareholders in developed countries, as compared to those investments in developing countries.

The Malaysian MNCs prefer to become involved in the international operation of developed countries due to the transfer of knowledge and technology. Most MNCs in Malaysia are involved in the service sectors in developed markets. According to Bala (1998), they compete with the local firms in the target developed markets in business areas like finance, insurance, transport, communication, hotels, restaurants and marketing chains. The MNCs in Malaysia can compete with those western firms in their home countries even without the benefit of advanced technology, since such investments are taking the form of fixed assets that require less technology. Therefore, the MNCs could survive and take the opportunity to acquire knowledge and learn the advanced technology in developed countries. MNCs are also able to develop and improve the operations in the home countries of the bidders when these knowledge and advanced technology shift to Malaysia, which would be beneficial to Malaysian local research and development. Hence, it would be a better choice to invest in developed countries.

In addition, there is another advantage for Malaysian MNCs in developed market from the perspective of risk of investing. The risks include the unilateral change of contract, rules or standards that lack considerations to MNCs, restrictions and discriminatory taxes that may deteriorate the MNCs' profit. Due to the infrastructure, banking system and human development, there is more risky operating environment in developing countries, as compared to larger developed countries. Therefore, these findings report that the negative wealth effect has been created in developing countries. The regression result for this variable indicates that positive wealth effects will be gained by Malaysian bidding firms when the target firm acquisitions are from developed countries.

Most of the control variables are statistically significant at the $5 \%$ and $10 \%$ levels. There is a negative sign for the LANGUAGE variable, which implies that Malaysian MNCs do not prefer to target the English-speaking country. This finding is not consistent with the earlier expectation from this study that Malaysian MNCs prefer English, as it is an internationally official and commonly used language among many countries.

This finding also seems to be conflict with previous findings that Malaysian MNCs prefer developed countries. For example, Malaysian MNCs mainly target the U.S., which is an English-speaking country, in exercising crossborder acquisition. However, Malaysian cross-border acquisition also targets the non-English-speaking countries such as Singapore, and other developed markets where English is not the only common language, such as Japan, Korea, some European countries, China and also most of the ASEAN countries.

Furthermore, Malaysia also has trade agreements with other countries that have encouraged international trade and foreign direct investment activities from Malaysia, such as the ASEAN Free Trade Area (AFTA), Malaysia's Free Trade Agreements (FTAs) with Japan, China, Korea, India, Australia and New Zealand. Nowadays, Malaysia has not even signed a single trade agreement with the U.S., but has had trade with other non-English-speaking countries. There are increasing numbers of projects and cross-border acquisitions by Malaysian MNCs going into non-English-speaking countries, such as Indonesia, Thailand and South Africa, if developed and developing status is not emphasized in the study.

Therefore, it is rational that Malaysia does not prefer English-speaking countries and favors other countries that use other language to influence the wealth gains to Malaysian bidders, even though English is the common language, thus facilitating communication among countries.

There are statistically significant results on both the rule of law index (LAWRULE), which represents the effectiveness of governance in a country and also telecommunication infrastructure (INFRATEL). Surprisingly, the rule of law index is negatively related to 
the wealth effect to Malaysian bidding firms, which indicates that the more rules implemented by the government leads to a lower wealth effect. This may also imply that Malaysian MNCs do not prefer government intervention. This is because the higher rule of law index might signal many restrictions imposed by the effective government, although a higher rule of law index also indicates better structure in governance. Thus, Malaysian MNCs do not prefer to operate in an over-structured governing environment. In short, a higher rule of law index in the target country leads to lower wealth of cross-border acquisitions.

The result of the telecommunication infrastructure is consistent with earlier expectations from this study that there is a positive relationship between wealth gains to the bidders and telecommunication infrastructure in the target country. This is because the better telecommunication infrastructure in the target country leads to better wealth effects to Malaysian bidders, since telecommunication connects the home and target countries and helps to facilitate the operations of foreign investment activities.

\section{Conclusion}

The purpose of the study is to examine the effect of macroeconomic variables on the wealth effects of crossborder acquisition by Malaysian multinational companies. In order to detect the market reaction to the cross-border acquisitions by Malaysian MNCs, the cumulative abnormal return of the stock of MNCs listed on the Bursa Malaysia has been used in the study. 165 cross-border acquisitions by Malaysian-bidding MNCs in 22 countries around the world during the period for 2000-2010 is the sample of the study. The study is expected to reveal the role of macroeconomic variables in determining the wealth gains of the cross-border acquisitions to Malaysian bidders. By achieving this, the study attempts to examine the cumulative abnormal return of each of the cross-border acquisition announcement by MNCs in Malaysia.

The findings of this study indicate that, there is a negative relationship between the foreign economic conditions and wealth gains to the bidding firms in Malaysia. This can explain cases in which the better foreign economic conditions lead to lower wealth gains or wealth effects experienced by Malaysian MNCs. Intense competition negatively effects the bidders that forcing them to make the wise strategies on enhancing quality, lowering their price and aggressively plan for raising advertising. This implies that the cross-border acquisition by Malaysian MNCs in the countries with expanding economic conditions might experience negative wealth gains.

In addition, this study discovered that the target country level of development is positively significant with wealth effects. These findings reveal that Malaysian MNCs prefer to conduct foreign investment activities in developed markets, when the international acquisitions would obtain higher wealth gains to bidders in developing countries. The transfer of knowledge and technology becomes the main motive on why the Malaysian MNCs favor to involved in the international operation of developed countries. There is another advantage for Malaysian MNCs in developed market from the perspective of risk of investing. The risks of the operating environment in developed countries are lower compared to the developed countries.

This finding also seems to suggest that Malaysia does not prefer English-speaking countries and favors other countries that use other language to influence the wealth gains to Malaysian bidders, even though English is the common language, thus facilitating communication among countries. The interesting results also documented in this study since the Malaysian MNCs do not prefer government intervention because the higher rule of law index might signal many restrictions imposed by the effective government, although a higher rule of law index also indicates better structure in governance. Thus, Malaysian MNCs do not prefer to operate in an over-structured governing environment. Meanwhile, the result of the telecommunication infrastructure shows that the better telecommunication infrastructure in the target country leads to better wealth effects to Malaysian bidders, since telecommunication connects the home and target countries and helps to facilitate the operations of foreign investment activities.

The implication from the findings is that the foreign economic condition and level of economy of the foreign country determine the wealth effect of the Malaysian crossborder acquisitions. Therefore, Malaysian MNCs should take these macroeconomic variables into consideration in order to increase their foreign investment value if they intend to venture abroad, particularly by using acquisition as an entry strategy. Thus, MNCs can then build an effective policy for their foreign investment activities that could lead to greater wealth gains for the firms or prevent from investing abroad in unprofitable projects that negatively impact wealth gains once they have the knowledge related to the effect of macroeconomic factors on wealth effects.

The perspective provided by this study is also useful to government policy makers. Malaysian cross-border acquisitions are expected to increase, since OFDI is becoming popular in Malaysia and the trend of using acquisitions for FDI activities among developed markets is increasing. Therefore, government could trade more internationally with developed countries in order to promote more FDI, as the findings of the study indicates that wealth gains are related to the investment in developed countries.

Furthermore, this study brings important insight to shareholders among the general public. For instance, shareholders can know how to assess the performance of acquisitions by Malaysian MNCs and also utilize the macroeconomic factors to make predictions for the movement of the share price in the market.

Besides, this study will add to the extant literature in Malaysian studies, since there are scarce studies related to foreign investment activities. This study can be treated as a leading study, since the research on cross-border acquisition from Malaysia is still fresh. Thus, this study aims to create a trend that will attract more researchers to conduct studies on acquisition issues. 
Bany Ariffin Amin Noordin, Fakarudin Kamarudin, Nazratul Aina Mohamad Anwar. Wealth Effect and Macroeconomics...

\section{References}

Anderson, E., \& Gatignon, H. (1986). Modes of Foreign Entry: A Transaction Cost Analysis and Propositions. Journal of International Business Studies, 17(3), 1-26. http://dx.doi:10.1057/palgrave.jibs.8490432

Bany-Ariffin, A. N., \& Fauzias, M. N. (2006). Wealth Effect of International Investment Announcements: Evidence from Developing Market. Asian Academy of Management Journal, 11(1), 49-65. http://web.usm.my/aamj/11.1.2006/aamj\% 2011-1-3.pdf

Bala, R. (1998). Malaysia's Investment Development Path. Malaysian Management Review, 4, 1-7. http://portal.mim. org.my /resources/MMR/9806/980602.htm

Bellak, C., Leibrecht, M., \& Damijan, J. P. (2009), Infrastructure Endowment and Corporate Income Taxes as Determinants of Foreign Direct Investment in Central and Eastern European Countries. The World Economy, 32, 267290. http://dx.doi: 10.1111/j.1467-9701.2008.01144.x

Billington, N. (1999). The Location of Foreign Direct Investment: An Empirical Analysis. Alied Economics, 31(1), 65-72. http://dx.doi: 10.1080/000368499324561

Biswas, R., Fraser, D. R., \& Mahajan, A. (1997). The International Market for Corporate Control: Evidence from Acquisitions of Financial Firms. Global Finance Journal, 8, 33-54. http://dx.doi:10.1016/S1044-0283(97)90004-1

Brown, S. J., \& Warner, J. B. (1985). Using Stock Returns: The Case of Event Studies. Journal of Financial Economics, 14, 3-31.http://dx.doi:10.1016/0304-405X(85)90042-X

Cartwright, S., \& Schoenberg, R (2006). Thirty Years of Mergers and Acquisitions Research: Recent Advances and Future Oortunities. British Journal of Management, 17,(1), pg 1-5. http://dx.doi: 10.1111/j.1467-8551.2006.00475.x

Evenett S. J. (2003). The Cross-border Mergers and Acquisitions Wave of the Late 1990s, National Bureau of Economic Research Working Paper no. 9655, Cambridge, MA. http://www.nber.org/papers/w9655.pdf

Fama, E. F. (1976). Foundation of Finance. New York: South Western College Publishing. http://faculty.chicagobooth.edu/ eugene.fama/research/

Fauzias, M. N. (1992). Corporate Takeover and Market Efficiency: The Malaysian Experience. Journal Pengurusan, 11, 75-94. http://ejournals.ukm.my/pengurusan/article/view/1615/1388

Fauzias (1993). Acquisition Announcement and Stock Price Behaviour: The Malaysian Experience. Journal Pengurusan 12, 85-109. http://journalarticle.ukm.my/7944/1/776-1483-1-SM.pdf

Frenkel M., Funke, K., \& Stadtmann, G. (2004). A Panel Analysis of Bilateral FDI Flows to Emerging Economics. Economic Systems, 28, 281-300. http://dx.doi:10.1016/j.ecosys.2004.01.005

Globerman, S., \& Shapiro, D. (2005). Assessing International Mergers and Acquisitions as a Mode of Foreign Direct Investment, In Governance, Multinationals and Growth 2005 - New Horizons in International Business, eds. Lorraine Eden and Wendy Dobson, Cheltenham: UK and Northampton, 68-99. http://128.118.178.162/eps/if/papers/0404/ 0404009.pdf

Heston, S. L., \& Rouwenhorst, K. G. (1994). Does Industrial Structures Explain the Benefits of International Diversification? Journal of Financial Economics, 36, 3-21. http://dx.doi:10.1016/0304-405X(94)90028-0

Hisey, K. B., \& Caves, R. E. (1985). Diversification and Choice of Country. Journal of International Business Studies, 16, 51-65. http://www.jstor.org/stable/154654

Homberg, F., Rost, K., \& Osterloh, M. (2009) Do Synergies Exist in Related Acquisitions? A Meta-Analysis of Acquisition Studies, Review of Managerial Science, 3 (2), 75-116. http://dx.doi:10.1007/s11846-009-0026-5

Kamarudin. F., Nasir, A. M., Yahya, M. H., Said, R. M. \& Nordin, B. A. A. (2014b). Islamic Banking Sectors in Gulf Cooperative Council Countries. Analysis on Revenue, Cost and Profit Efficiency Concepts. Journal of Economic Cooperation and Development 35, 1-42 http://www.sesrtcic.org/jecd/jecd_articles/ART12092401-2.pdf

Kamarudin, F., Nordin, B. A. A., \& Nasir, A. M. (2013). Price Efficiency and Returns to Scale of Banking Sector in Gulf Cooperative Council Countries: Empirical Evidence from Islamic and Conventional Banks. Economic Computation and Economic Cybernetics Studies and Research, 47(3), 215-236 http://www.ecocyb.ase.ro/nr.3.pdf/Fakarudin\%20 Kamarudina.pdf

Kamarudin, F., Nordin, B. A. A., Muhammad, J., \& Hamid, M. A. A. (2014a). Cost, Revenue and Profit Efficiency of Islamic and Conventional Banking Sector: Empirical Evidence from Gulf Cooperative Council Countries. Global Business Review, 15(1), 1-24 http://dx.doi: 10.1177/0972150913515579

Kennedy, P. (2008). A guide to econometrics. Malden: Blackwell publishing. http://as.wiley.com/WileyCDA/WileyTitle/ productCd-EHEP001025.html

Kiymaz, H., \& Mukherjee, T. K. (2000). The Impact of Country Diversification on Wealth Effects In Crossborder Mergers. Financial Review, 35, 37-58. http://dx.doi: 10.1111/j.1540-6288.2000.tb01413.x

Kiymaz, H. (2004). Cross-Border Acquisitions of US. Financial Institutions: Impact of Macroeconomic Factors. Journal of 
Banking and Finance, 28, 1413-1439. http://dx.doi:10.1016/S0378-4266(03)00125-0

Kueh, J, S.H., Puah, C.H., \& Shazali, A.M. (2009). Empirical Analysis on Emerging Issues of Malaysia Outward FDI from Macroeconomic Perspective. Munich Personal RePEc Archive. http://mpra.ub.uni-muenchen.de/37680/1/Outward_ FDI.pdf

Lee, S. P., \& Mansor, M. I. (2008). Long-term Share Performance of Malaysian Biding Firms. http://eprints.um.edu.my/ 828/1/LeeSiewPeng-Final.pdf Accessed 28 January 2010.

Madura, J., \& Wiant, K. J. (1994). Long-term Valuation Effects of Bank Acquisitions. Journal of Banking and Finance, 18, 1135-1154. http://dx.doi:10.1016/0378-4266(94)00064-6

Manzon,G.B., Sharp, D.J., \& Travlos, N.G. ( 1994) An Empirical Study of the Consequences of US. Tax Rules for International Acquisitions by US. Firms, Journal of Finance, 49, 1893-104. .http://dx.doi: 10.1111/j.1540-6261. 1994.tb04786.x

Markusen, J. R. (1998). Multinational Firms, Location and Trade, the World Economy, 21, 6, $733-56$. http://dx.doi: 10.1111/1467-9701.00161

Rossi, S., \& Volpin, P. (2004). Cross-country Determinants of Mergers and Acquisitions, Journal of Financial Economics, 74: 277-304. http://dx.doi:10.1016/j.jfineco.2003.10.001

Schneider, F., \& Frey, B. S. (1985). Economic and Political Determinants of Foreign Direct Investment. World Development, 13(2), 161-175. http://dx.doi:10.1016/0305-750X(85)90002-6

Sufian, F., \& Kamarudin, F. (2014). Efficiency and Returns to Scale in the Bangladesh Banking Sector: Empirical Evidence from the Slack-Based DEA Method. Inzinerine Ekonomika-Engineering Economics, 25(5), 549-557 http://dx.doi.org/10.5755/j01.ee.25.5.5035

Sufian, F., Kamarudin, F., \& Noor, N. H. H. M. (2012). Determinants of Revenue Efficiency in the Malaysian Islamic Banking Sector. Journal of King Abdulaziz: Islamic Economics 25, (2), 195-224 http://dx.doi: 10.4197 / Islec. 25-2.7

Sufian, F., Kamarudin, F., \& Noor, NHHM. (2013a). Assessing the Revenue Efficiency of Domestic and Foreign Islamic Banks: Empirical Evidence from Malaysia. Jurnal Pengurusan, 37(1), 77-90. http://ejournal.ukm.my/pengurusan/ article/ view/3629/2115

Sufian, F., Kamarudin, F., \& Noor, N. H. H. M. (2014). Revenue Efficiency and Returns to Scale in Islamic Banks: Empirical Evidence from Malaysia. Journal of Economic Cooperation and Development, 35(1), 47-80. http://www.sesrtcic.org/jecd/jecd_articles/ART12040601-2.pdf

Sufian, F., Muhammad, J., Nordin, B. A. A., Yahya, M. H., \& Kamarudin, F. (2013b). Assessing the Effect of Mergers and Acquisition on Revenue Efficiency: Evidence from Malaysian Banking Sector. International Journal of Economic Research, 10(2), 309-325. http://www.serialsjournals.com/serialjournalmanager/pdf/1423736381.pdf

Trevino, L. J., Daniels, J. D., \& Arbelaez, H. (2002). Market Reform and FDI in Latin America: an Empirical Investigation. Transnational Corporations, 11(1), 29-48. http://unctad.org/en/Docs/iteiit29v11n1a2_en.pdf

UNCTAD 2010. World Investment Report (2010). New York: United Nations. http://unctad.org/en/docs/wir 2010_en.pdf

Waheed, A., \& Mathur, I. (1995). Wealth Effects of Foreign Expansion by US. Banks. Journal of Banking and Finance, 19, 823-842. http://dx.doi:10.1016/0378-4266(95)00085-U

The article has been reviewed.

Received in April, 2015; accepted in October, 2015. 